\title{
Why has a large Legionnaires' disease outbreak been absent from public debate?
}

Felisbela Lopes ${ }^{(a)}$

Rita Araújo (b)

Lopes F, Araújo R. Um grande surto de Legionella ausente do debate público. Interface (Botucatu). 2017; 21(63):957-67.

The Legionnaires' disease outbreak that hit Portugal in November 2014 was the third largest worldwide and was declared a "great public health emergency". Nonetheless, the Portuguese outbreak, despite killing 12 people and infecting 375 others did not promote extensive media coverage, nor did it make it into the political debate. We conducted a quantitative analysis of 83 news pieces on Legionella published in four national newspapers, and interviewed the journalists who covered this outbreak. The communication process was controlled by a small group of official sources and the outbreak was pushed away from news lineups due to two political scandals. The production of another news wave made the outbreak's news wave to break prematurely.

Keywords: Legionnaires' disease. Disease outbreaks. Health communication. Journalism. News waves.
O surto de Legionella que atingiu Portugal em novembro de 2014 foi o terceiro maior em nível mundial, constituindo "uma grande emergência de saúde pública". Ainda assim, o surto português não promoveu uma longa cobertura mediática, apesar das 12 mortes e 375 pessoas infetadas. Nem entrou no debate político. Fizemos uma análise quantitativa das 83 notícias sobre Legionella publicadas em quatro jornais nacionais, e conduzimos entrevistas com os jornalistas que cobriram este surto. O processo comunicativo foi controlado por um pequeno grupo de fontes oficiais, e o surto foi rapidamente afastado dos alinhamentos noticiosos, sendo substituído por dois escândalos políticos. A produção de outra onda noticiosa fez com que a onda noticiosa do surto de Legionella se quebrasse prematuramente.

Palavras-chave: Legionella. Surtos de doenças. Comunicação em saúde. Jornalismo. Ondas noticiosas.

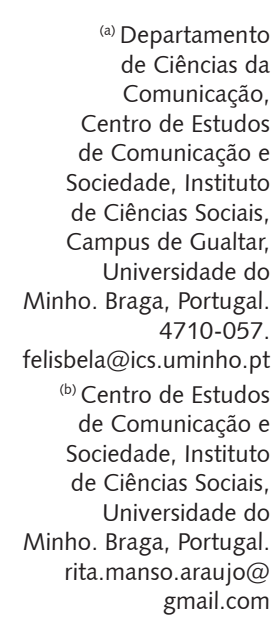

(c) Interface comunicação saúde educação
Rita Araújo 


\section{Literature Review}

\section{The media's power in setting the public agenda}

Media have the power to set public and political agendas by promoting the coverage of certain issues instead of others. We argue that the agenda setting theory alone is not enough to explain the way certain issues or news sources become part of the media agenda, while others do not. Knowing the news making process is a result of journalists' constant choices, one needs to take a step back and understand what kind of variables influence these options. We are referring to agenda building, which is a process that begins in Political Science and was first introduced in the literature by Cobb and Elder ${ }^{1}$ in a study on politics and the news in the 1970s. This process occurs before agenda setting and it is concerned with the reasons why some issues or sources climb the media agenda and others do not. Several authors, especially north-Americans, dedicated their research to studying agenda building and agenda setting, contributing to the birth of several concepts and perspectives. Indeed, agenda building can also be called "first-level" agenda setting, being its core theoretical assertion that the media concern with 'objects' in the news leads to an increased public concern with those same 'objects'. In other words, the media tell the public what issues to think about ${ }^{2}$. Matthew Nisbet ${ }^{3}$ says that the agenda building refers to the "process by which media organizations and journalists feature, emphasize, and/or select certain events, issues, or sources to cover over others".

There are several factors influencing the agenda building process, from economic and cultural variables to the reporter's perceptions towards the world he/she lives in. The north-American researcher Rita Colistra ${ }^{4}$ defines agenda building as the process of influencing media choices. Reporters' choices are not random, and they are related to one's previous knowledge, culture or background. The news frame, the news sources, and the reporter's own characteristics may influence the agenda building process.

In the past few years, there has been a growing organization and professionalization of news sources, which makes them have a more active role in news making. They have sophisticated public relations tools and often work in public relations offices where they have a great power in setting the media agenda. Nowadays, there are more sources and they are more organized than ever. Besides, they "are aware of the journalists' work, which allows them to anticipate their limitations and expectations" ${ }^{15}$. According to the results of a research promoted by Len-Ríos and her co-workers ${ }^{6}$ on health news agenda building, "when developing health news reports, journalists often use information that comes in the form of 'information subsidies'". Information subsidies are ready-to-publish information usually fed to the journalists by organized sources. Routine channels used by public relations professionals, like press releases, press conferences and other pseudo-events are an example of these kind of information subsidies.

In the area of science and health, the literature suggests that general assignment reporters depend on subsidies because they, themselves, may know less about the story subject, and that beat or specialty reporters may use them as a means to meet deadline pressures ${ }^{6}$. (p. 315)

Even though we do not reject the power of news sources in setting the media agenda, it is our belief that journalists must keep having a major role in this process. We perceive media agenda as a result of a commitment between journalists and news sources, which may or may not be organized ones. Hence, the agenda building process is a negotiation between journalists and news sources, and only a commitment between both parts can set the media agenda.

The media's power may be perceived by the generation of news waves, which happened in the outbreak of Legionnaires' disease. "Every now and then the daily news media suddenly generate surprisingly high news waves on one specific story"7. The thing about news waves is that "hardly any news editor is able to resist the temptation of such an attractive story; it must be reported, because the competition is doing so, because it has consequences for main figures in the public arena and, of course, because the massive news wave itself is news ${ }^{7 "}$ (p. 509). 
Sometimes journalists go after a story that is not that important, which creates a separation between the reality and the media's representation of reality. The media end up making their own reality, which turns that one story into the most important one for a few days or weeks. And "during these news waves, news coverage seems to develop a life of its own"7.

\section{A news wave that has broken prematurely}

The news media tend to cover disruptive events (such as car crashes), routine events (like parliamentary discussions), or continuous events (an example would be a football championship). We face a news wave whenever an unexpected event manages to be on top of the news line-up for several days. This news wave is characterized by an intensive media coverage which then reaches a peak, when the news itself becomes even more important.

The world's third biggest outbreak of Legionnaires' disease hit Portugal in November 2014 and it promoted a news wave that broke prematurely. This means that the news wave did not reach its peak, it broke just right before reaching its climax. When Portuguese authorities identified the ones responsible for this outbreak, the media stopped covering this event.

On November $8^{\text {th }} 2014$ the Portuguese media began their coverage of the Legionnaires' disease outbreak. The news framing was justified by a high number of hospitalized people (27). The day after it began, the outbreak hit the front pages of the main national newspapers, where it stood for roughly two weeks. At last, the authorities pointed out responsibilities on a fertilizers company and the outbreak left the top of the news line-ups. It was then replaced by a political scandal involving the illegal attribution of golden visas. A week later, it was pushed away to the news margins with the arrest of the Portuguese former prime-minister who was then a suspect of fiscal fraud, corruption and money laundering. This constitutes a classical example of a news wave, yet showing a single characteristic. The people responsible for the outbreak were soon identified but at that same moment Legionella is pushed away from the news, which is extraordinary.

News focused on the high number of hospitalized people: they were led to the same hospital, at the same time. This is the key event characteristic of these kinds of phenomena ${ }^{7}$. The following days, this wave was supported by three news frames: the increasing number of people infected/killed; the search for responsibility; and the perceptions of the affected population. Frames are mainly focused on the first two aspects and they promote an intense news coverage during the first days of the outbreak. Had the news wave followed the normal behavior, and the intensity of the news coverage would have evolved towards the number of deaths and would reach its highest peak the day responsibilities were identified. However, when the authorities revealed they were close to finding whoever was responsible for the outbreak, the media lost interest in the coverage and they promoted a silence around this issue as soon as responsibilities were named. At the time, other two (political) events were drawing a huge amount of media coverage. Nonetheless, that could not have justified the media's loss of interest in the outbreak. Because this was one of the biggest outbreaks of Legionnaires' disease worldwide and it should have motivated an intense coverage, at least until the moment when responsibilities were named. Indeed, that did not happen and the interviews we conducted with the reporters who covered this outbreak show that they too recognize this case was an exception that should not have taken place.

Almost every newspaper edition puts Legionella on the front page several times during the first week of the outbreak. This outbreak was perceived as a major news event, and newsrooms had two or three journalists working on it permanently. It was focused on a small dimension city (Vila Franca de Xira), nearly $40 \mathrm{~km}$ away from Lisbon, the Portuguese capital. Being so close to Lisbon, it had an intense coverage when it first began because most newsrooms are located there.

After two weeks of intense news production, on November $21^{\text {st }}$ people had the confirmation of responsibilities. Official news sources confirmed that the Legionella strains found in sick people were coincident with lab tests conducted on a cooling tower of ADP Fertilizers (a fertilizers company). At this point, this information had already been informally given to a number of journalists a week before. And it was then presented at a press conference by the Director-General of Health, who read a joint statement by a series of official organizations: the Directorate-General of Health; the National Institute 
of Health; the Regional Health Administration of the Lisbon area; and the Environmental Inspectorate. These authorities formed a multidisciplinary task force whose job was to assess and investigate the outbreak, which shows a strong institutional presence.

The joint statement by the task force should have been enough to keep the subject on top of news line-ups, since journalists had been looking for answers for days now, and one would expect the announcement of responsibilities to promote a media coverage at least as intense as previously. None of that happened, and part of the explanation lies in the unforeseen arrest of the Portuguese former primeminister José Sócrates, who was accused of fiscal fraud, money laundering and corruption. A week before, non-identified sources had already pointed out responsibilities in the outbreak. Likewise, this did not draw media's attention because another scandal emerged: the illegal attribution of golden visas.

It is visible that this news wave has particular characteristics, since the media stopped acting like a reflector/mirror of reality as soon as the outbreak reached its peak. The outbreak of Legionnaires' disease becomes news on November $8^{\text {th }}$ and has an intense coverage until the $15^{\text {th }}$. It is only on November $16^{\text {th }}$ that the news wave starts to fade away, giving way to another news wave. From this moment on, journalists change their attention from the Legionnaires' disease to the golden visas' scandal, even though the outbreak was not yet solved. Quite on the contrary, there still were a lot of people being admitted to the hospital due to this disease. A week after, a new political scandal rises. On this very same day, official authorities identify those responsible for the Legionnaires' disease outbreak, although this development is almost unperceivable in the news. And soon the outbreak is almost invisible.

The appearance of several news waves reporting on serious events shows that the media are uncomfortable with more than one news wave. The appearance of a news wave soon replaces the previous one, and news criteria are not always taken into account. On this outbreak, the decrease of news coverage is coincident with a key-moment of the case. Even though news waves are always shallow water waves, since they form and fade away very quickly, some issues should be taken into account. Namely, the moment when they fade away may also be a newsworthy moment within the event. And this was the case with Legionnaires' disease. We would say that news sources are not responsible for that, since media are the ones who chose to push this outbreak to the silent margins right at its peak. This happened because the media did not manage to promote two simultaneous news waves.

\section{Methods}

This research is part of a broader PhD project on the coverage of health in the Portuguese press. Our goal was to analyze the way the Legionnaires' disease outbreak was covered by the Portuguese press. We analyzed all the Legionnaires' disease-related news published in four national newspapers: Público, Jornal de Notícias and Diário de Notícias (daily newspapers) and Expresso (weekly newspaper). Our sample is non probabilistic and we chose these newspapers because they have different periodicity and editorial lines. We analyzed the main sections of these newspapers and left aside op-eds. Our period of analysis is the month of November 2014 and is justified by the outbreak itself.

We then conducted a quantitative analysis based on descriptive statistics, through the data analysis software SPSS. We studied the following variables: year of analysis, date, newspaper, title, disease, news genre, theme, time of the news, size, place of the news, presence and number of news sources. As for the news sources' analysis, we were interested in knowing who they were and what their job was. In order to do so, we looked for the following variables: presence/absence of news sources; number of quoted sources; geographical place of the source; sex; identification; status; and medical specialty.

This quantitative analysis allowed us to have a complete overview of the Legionnaires' disease outbreak. Therefore, we conducted a qualitative analysis through interviews with the reporters who covered this outbreak within the analyzed newspapers. 


\section{Interviews and participants}

We interviewed eight reporters, whose answers were emailed to us. The participants are two journalists from Jornal de Notícias, and Diário de Notícias, three from Público and one reporter from Expresso. Our sample has six female journalists and two males. Even though our interviewees did not ask for anonymity, we decided not to identify them because we believe it would not add relevance to our analysis. This is also consistent with the international trend ${ }^{8-10}$.

We asked them the following questions:

- What do you think was the main obstacle in covering this outbreak and what was helpful to the media coverage?

- The Legionnaires' disease outbreak did not make it into the political debate, even though it was a major outbreak; why?

- Two weeks after the beginning, the outbreak disappeared from the front pages. This was also the moment when responsibilities were appointed; why?

- During the coverage of this outbreak, did reporters promote social alarm or did they promote health literacy? Why?

We aimed at answering some unanswered questions in our quantitative analysis by finding some different news frames. These questions seek to understand the whole news building process on the Legionnaires' disease outbreak.

\section{Results and discussion}

\section{An outbreak that was invisible from political debate}

During two weeks, three of the main National daily newspapers (Público, Diário de Notícias and Jornal de Notícias) published 81 texts on Legionella, almost two daily news pieces. The weekly newspaper Expresso published one piece in each edition. So our corpus has 83 news pieces. As for the size of the news, our analysis shows that most texts are medium sized $(55.4 \%)$ and a significant part is long sized $(21.7 \%)$. Almost every newspaper edition put Legionella on the front page several times during the first week of the outbreak.

In order to understand journalists' perceptions, we conducted interviews to the reporters who covered this outbreak. And most of them chose the moment when the origin of the outbreak is revealed as one of the most newsworthy. However, they do not mention newspapers not highlighting that moment. Nonetheless, some reporters believe the arrest of a former prime-minister is a plausible explanation for the decrease in the outbreak's coverage. Journalists explain the wave breaking by the absence of new admittances to the hospital and the fast detection of the outbreak's origin. They admit there was no political responsibility and so the case would be transferred to the courts of law, where timings are different from media timings. "In a way, finding out the outbreak's origin was the missing piece. From that moment on, the issue kept being updated with numbers of both admitted and deceased people but was no longer able to compete with daily news", a journalist says. This is actually the opinion of most of the interviewees.

Nonetheless, there are some loose ends in this outbreak's media coverage, recognized by all the reporters who worked the case. "We are yet to understand what happened or will happen to those responsible for the outbreak", a journalist says. Another reporter recognizes that "this event would deserve a lot more", but "small newsrooms and the never-stopping daily news make it easy to forget an issue". This journalist admits that "it would take a great amount of imagination, research and energy to bring an issue like that back to the media agenda".

Six months after the beginning of the outbreak, the Portuguese press would go back to its coverage: "Victims wait for outcomes". During that time, there were 161 crime complaints 
filed against unknowns and still with no replies. The judicial investigation was not solved and compensations were yet to be defined (Jornal de Notícias, May $9^{\text {th }}$ 2015). On a first phase, the media speech contributed to informing people on the outbreak and to neutralizing social alarm situations. But the absence of discussion on the long run made it all the more difficult to help affected people.

The analyzed newspapers show no comments from the political parties and the government did not contribute to speculations on the outbreak. The Portuguese press published statements the Ministers of Health and Environment made at press conferences, which are controlled environments, but soon the media lost interest in this outbreak, which is an unobserved behavior in these risk situations. Both Influenza A and Ebola outbreaks did not promote this media behavior. Even though the Ebola outbreak did not threat Portugal, it motivated a great deal of coverage in the Portuguese media ${ }^{11}$. During the Influenza A epidemic, there was an intense public debate that influenced both the political and the media fields. We even referred to a media pandemic, a pandemic that took place in the media rather than in the real life events. These results are shown in a research in which we analyzed 655 news published in three Portuguese newspapers ${ }^{12,13}$.

When it comes to the Legionnaires' disease outbreak, the news wave suddenly vanished due to several factors. First, because responsibilities were soon named (two weeks after the beginning of the outbreak, both the Government and health authorities would hold a press conference presenting the name of the company with whom lied responsibilities). Second, because the political authorities would permanently inform the media, leaving (almost) no questions unanswered (thus neutralizing any possible speculation). This last factor was central to the similarity of the news discourse promoted by all the media. The Director-General of Health was a crucial actor, since he was the one controlling the strategy of communication.

We will now analyze the news sources quoted by journalists during the Legionnaires' disease outbreak. The research we have been conducting on the media coverage of health in the Portuguese press since $2008^{14}$ shows that only a small percentage of news sources are non-identified. During the Legionnaires' disease outbreak, $83.3 \%$ of the sources are identified and only $16.7 \%$ are nonidentified.

Since the outbreak was focused in a city near the capital, almost half of news sources ( $44.1 \%)$ are located in the Greater Lisbon area. The other half talks on a national level, as the Minister of Health. More than $75 \%$ of news sources are people, which means that documental sources and media are not very present in our sample (8.4\%). Male sources are predominant.

When it comes to news sources status (see Table 1), there is a predominance of official sources. Nonetheless, the media made both the common citizen and patients quite visible (26.9\%) in the news. They are the second most quoted group, but there are differences between these two categories. While official sources are represented by a small group of people who deal daily with the media and show a clear communication strategy, common citizens talk on an individual level and show no articulation among them. Therefore, even though their messages express complaints, they do not have half the impact they could if well-defined.

Table 1. News Sources Status

\begin{tabular}{llrr}
\hline & & \multicolumn{1}{c}{$\%$} & Totals \\
\hline Official sources & Within the health field & 25.5 & \\
& Outside the health field & 4.2 & 29.7 \\
Citizens & Common citizen & 21.3 & \\
& Patients & 5.6 & 26.9 \\
Specialized sources & Within the health field & 13.4 & \\
& Outside the health field & 11.4 & 24.8 \\
Media & & & 4.4 \\
Documents & Within the health field & 2.7 & 3 \\
Others & Outside the health field & 0.3 & \\
& & & 11.2 \\
\hline
\end{tabular}


The predominance of official sources is not a singular characteristic of Legionnaires' disease coverage. Previous studies on the coverage of Influenza $A^{12,13}$, E. Coli ${ }^{15}$ and Dengue ${ }^{16}$ showed a prevalence of official sources. What stands out during this outbreak is the visibility of patients (and their families) and the common-citizen. It promoted a significant number of news features that presented several sources. By increasing the number of sources quoted, journalists were able to include the common-citizen's voice. These sources were often making complaints or expressing fears and anxiety towards an outbreak which treatment was unknown to them. Still, they were neutralized by an official discourse often made by three people: the Ministers of Health and of Environment, and the Director-General of Health. Even though these official sources eliminated any chance of a public debate, they were not responsible for the breaking of the news wave they would daily promote through the information conveyed to the media.

As soon as the outbreak started, the media's concern was shared between counting deaths and hospitalized people, on the one hand, and identifying responsibilities, on the other. Data was made available to the media. And the origin of the outbreak, which could become controversial, was soon silenced by Portuguese authorities, under a secrecy clause determined in the penal code which does not allow undergoing investigations to be disclosed.

On November $7^{\text {th }}$, the Directorate-General of Health reported on an abnormal number of people infected with Legionnaires' disease in Vila Franca de Xira. A task force was created right away, and the minister of health himself presided it and constantly monitored the situation. The media got a lot of attention. Besides the conveying of information to the media in general, official authorities also made themselves available to individual questions posed by a given newspaper (the specificity of some quotes makes this visible in the news). Despite the openness, officials felt the need to hide some information that was the most newsworthy: what was the origin of the outbreak. However, official sources led people into thinking that there was an undergoing investigation and that the outcome would soon be known.

Five days after announcing the outbreak, newspapers changed from the public health frame to the legal one. "People responsible for Legionnaires' disease outbreak may serve eight years in jail" (Diário de Notícias, front page). That same day, Jornal de Notícias published a small piece saying that "the responsible must be punished". Official sources consistently refused to comment on this frame, which did not help journalists go deeper. Officials would not talk about an undergoing investigation and no information was leaked from the judicial field. On top of that, the issue would not reach the political field. So who would journalists talk to in order to widen this frame?

Our sample shows 287 news sources, and only five belong to the judicial field. This frame was a dead end, since pursuing it would imply a violation of the law. It was only on November $21^{\text {st }}$ that the origin of the outbreak was revealed, in a press conference promoted by the same small group of official sources who had been controlling and managing public information. The Minister of Health himself announces the name of the company responsible for the outbreak and says that this public health threat is now over. This becomes the last newsworthy moment of the two-week news wave. There was a circular structure of information spreading from official sources who would only make available information they thought suitable. This would then reach them the next day, as news they would be controlling.

Citizens would complain about the lack of information and consequent social alarm (Jornal de Notícias, November $10^{\text {th }}$ ) and hospitals would claim that "there was a rupture caused by this situation" (Diário de Notícias, November 11 $1^{\text {th }}$. However, none of these statements would be strong enough to stimulate a political discussion within the public space. Perhaps because those who were in charge of managing a crisis situation would keep talking - always delivering strategic statements.

Several declarations were jointly given by the Ministers of Health and Environment, and the Director-General of Health. They used numerous communication strategies to express the same message. Besides describing the outbreak, press releases were a tool to tranquilizing people. The message conveyed by them was that the situation was serious, but it was under investigation.

Plus, we would like to highlight that this Legionnaires' disease outbreak did not involve pharmaceutical interests, since no medical product was ever an option. There are only two 
pharmaceutical sources from a sample of 287 quoted sources. This shows the lack of economic interests that could struggle for visibility in the public space, as it was the case during the Influenza A pandemic in 2009 ${ }^{12,13}$. Back then, pharmaceuticals had a genuine interest in promoting the need for a vaccine. Contrarily, the Legionnaires' disease outbreak was mainly a public health and environmental crime case that was developed in a small. Part of the explanation to the loss of media interest could lie here. Since there was no health lobbying in order to keep this issue in the media agenda and political parties did not show an interest themselves, the media could easily push it to the silent margins. Also, the public's interest was not so wide, since this outbreak only affected a small city.

The interviews conducted to journalists show that not all of them agree this issue was hidden from political debate or totally pushed away to the silent margins. A reporter says that "the issue was discussed within the Parliament" and "non-governmental organizations in the environment area alerted for the outbreak".

However, that did not promote a national continuous debate. One journalist explains the lack of political discussion: "What was happening was not related to politics, it was an event whose responsibility was clearly on the polluter's side and not on the regulator". The realization that the outbreak was seen as a fatality for political power is common to other reporters: "All the political parties realized that this was a serious public health issue, and that the health and environment authorities gave an effective and fast answer". Hence, both the task force that was created to control communications with the media and the quick investigation into the outbreak's origin made public debate almost inexistent. From the very first day, this outbreak was always away from the political discussion and was seen as a technical matter. Eventually, that did not promote its public debate.

\section{Final remarks}

In the past few years, public health has been threatened by severe outbreaks that were largely covered by the media, as Influenza $A^{12,13}$, E. coli ${ }^{15}$ and Ebola ${ }^{11}$. However, this Legionnaires' disease outbreak did not promote the same media coverage as others, although it was the world's third largest outbreak. Why? We would point to a number of reasons that had the power to push this issue away from the news agenda.

The Influenza A outbreak started abroad and promoted a global fear of contagion. On the contrary, the current Legionnaires' disease outbreak was confined to Portugal, specifically to a small city. There was never a threat that it would travel, which did not raise panic among the population. Furthermore, the people's interest in Legionnaires' disease-related news was very small. And Vila Franca de Xira being a small city has also contributed to this (almost) lack of interest. Journalists were well aware of that limitation and knew that this outbreak would not be kept in the media agenda for long. During the Influenza A pandemic, there was a global threat; during the E. Coli outbreak, Europe was under risk of contamination. Those threats promoted a collective fear that did not respect borders, and so they motivated a wider coverage. The contagion effect was also felt within the media coverage of these cases.

The main Portuguese newspapers had several reporters dedicated to this outbreak from the very beginning, and they worked the issue either from the newsroom or in the field. In the first week there was an investment from the media. Journalists interviewed specialists and, most importantly, they published infographics explaining the outbreak and focusing on health literacy aspects.

Health and political authorities joined efforts from the beginning, in order to control information and to present the same description of the facts. Other than official statements, there was a clear silence from other types of sources. At the outbreak's peak there were no leaks of information to promote any noise around this issue, which did not stimulate a public discussion. Hence, the Ministries of Health and Environment agreed on a communication strategy that would make the ministers themselves the spokespeople for this outbreak. They would communicate through press releases 
or press conferences, and they were always available to enlighten journalists. Communication was promoted through direct speech and on the highest level of authority, leaving press officers and nonidentified sources almost silent.

Moreover, this outbreak was not surrounded by economic interests, since it did not involve vaccinations or great treatments. Unlike what happened with Influenza A or Ebola, the pharmaceutical industry had no particular interest in Legionnaires' disease. This fact may also contribute to the (existence or absence of) news coverage of the outbreak.

All of these may help explain this outbreak was pushed away from the news agenda so soon. However, they do not explain why the media's decision not to follow-up on the outbreak during one of its most important moments, finding those responsible. The lack of media's interest may be explained by the generation of another news wave that emerged from the political field and involved a public interest event: the suspicions of corruption by a former prime-minister. The media has difficulties in dealing with two different news waves, which has made the first news wave to break prematurely. That should not have happened, because those responsible for the outbreak should have been part of a wide coverage. They not being part of the news was a journalistic choice made by all the national newspapers. Newsrooms chose to cover the arrest of the former prime-minister by alleged corruption, and that was the event that swallowed the Legionnaires' disease outbreak. Consequently, public authorities themselves would drop the case and the judicial follow-up would take so long that whoever was responsible was not forced to reward the victims within a short period of time. It all could have been different, had the media made room for both news waves.

Without media pressure, the outbreak was kept away from the public scrutiny and from the priorities of institutions with the power to compensate all the victims. Six months later, there was a small news in one of the Portuguese newspapers that reported on 161 crime complaints against unknown people. These complaints were filled by those whose family died or became sick from the outbreak. Had the news wave not been broken so prematurely, and the outcomes could have been different.

From the first day to the moment when the outbreak disappeared from the top of the news lineups, there is a clear presence of the agenda building process. When the media realizes they are facing an outbreak, they make an editorial decision and the Legionnaires' disease outbreak is given high news-worthiness. This decision happens before the news sources make any moves, which indicates that journalists were the ones who made official sources go public and give information on a regular basis. On the other hand, despite the political powers' concerns in controlling all the information that was made public, the media searched for alternative ways of telling this story. They left the newsrooms and published features while talking to the victims and their families, supporting their news texts with infographics that helped contextualize the outbreak. The Portuguese media coverage of this outbreak contributed to a representation of reality that was not always coincident with the official version. In spite of that, there were no radical differences between what was portrayed by the media and the information conveyed by the political power. In the end, journalists had so much control over the agenda building process that they pulled the outbreak from the news when the official sources most wanted it highlighted.

\section{Collaborators}

Felisbela Lopes had an active participation in the discussion of results and in the review and approval of the final version of this work. Rita Araújo had an active participation in the discussion of results and in the review and approval of the final version of this work. 


\section{References}

1. Cobb R, Keith-Ross J, Ross MH. Agenda building as a comparative political process. Am Polit Sci Rev. 1976; 70(1):126-38.

2. Kiousis S, Mitrook M, Wu X, Seltzer T. First-and second-level agenda-building and agenda-setting effects: exploring the linkages among candidate news releases, media coverage, and public opinion during the 2002 Florida Gubernatorial Election. J Public Relat Res. 2006; 18(3):265-

85.

3. Nisbet MC. Agenda building. In: Donsbach W. International encyclopedia of communication. New York: Blackwell Publishing; 2008. p. 1-5.

4. Colistra R. Shaping and cutting the media agenda: television reporters' perceptions of agenda- and frame-building and agenda-cutting influences. Journal Commun Monogr. 2012; 14(2):85-146.

5. Neveu É. Sociologia do jornalismo. Porto: Porto Editora; 2005.

6. Len-Rios ME, Hinnant A, Park SA, Cameron GT, Frisby CM, Lee Y. Health news agenda building: journalists' perceptions of the role of public relations. Journal Mass Commun $\mathrm{Q}$. 2009; 86(2):315-31.

7. Vasterman PLM. Self-reinforcing news waves, journalistic standards and the construction of social problems. Eur Commun. 2005; 20(4):508-30.

8. Tanner AH, Friedman DB, Zheng Y. Influences on the construction of health news: the reporting practices of local television news health journalists. J Broadcast Electron Media. 2015; 59(2):359-76.

9. Friedman DB, Tanner AH, Rose ID. Health journalists' perceptions of their communities and implications for the delivery of health information in the news. J Community Health. 2014; 39(2):378-85.

10. Forsyth R, Morrell B, Lipworth W, Kerridge I, Jordens CF, Chapman S. Health journalists' perceptions of their professional roles and responsibilities for ensuring the veracity of reports of health research. J Mass Media Ethics. 2012; 27(2):130-41.

11. Neto I, Araújo R, Lopes F. Ebola: from newspaper to twitter. A study of coverage and engagement promoted by social media platforms. Commun Soc. Forthcoming 2016.

12. Lopes F, Ruão T, Marinho S. Gripe A na imprensa portuguesa: uma doença em notícia através de uma organizada estratégia de comunicação. Obs. 2010; 4(4):139-56.

13. Lopes F, Ruão T, Marinho S, Araújo R. A media pandemic: influenza A in Portuguese newspapers. Int Healthc Manag. 2012; 5(1):19-27.

14. Lopes F, Marinho S, Fernandes L, Araújo R, Gomes S. A saúde em notícia na imprensa portuguesa entre setembro de 2010 e junho 2013. In: Lopes F,Rerão T, Marinho S, Coelho ZP, Fernandes L, Araujo R, et al. A saúde em notícia: repensando práticas de comunicação. Braga: Centro de Estudos de Comunicação e Sociedade, Universidade do Minho; 2013. p. 56-80.

15. Lopes F, Ruão T, Marinho S, Araújo R. Escherichia coli: a disease in the news through speeches of uncertainty and contradiction. Int J Healthc Manag. 2013; 6(1):51-62.

16. Araújo R, Lopes F. A mediatização da dengue na imprensa portuguesa: os casos do público, expresso. J Obs. 2014; 8(1):49-68. 
Lopes F, Araújo R. Un gran brote de Legionella ausente del debate público. Interface (Botucatu). 2017; 21(63):957-67.

El brote de Legionella desencadenado en Portugal en noviembre de 2014 fue el tercero mayor en el ámbito mundial, constituyendo "una gran emergencia de salud pública". Aún así, el brote portugués no promovió una gran cobertura de los medios, a pesar de las 12 muertes y 375 personas infectadas. Tampoco entró en el debate político. Realizamos un análisis cuantitativo de las 83 noticias sobre Legionella publicadas en cuatro periódicos nacionales y realizamos entrevistas con los periodistas que cubrieron el brote. El proceso comunicativo fue controlado por un pequeño grupo de fuentes oficiales y el brote fue rápidamente alejado de los alineamientos de noticias, siendo sustituido por dos escándalos políticos. La producción de otra onda de noticias hizo que la onda de noticias del brote de Legionella se rompiera prematuramente.

Palabras clave: Legionella. Brotes de enfermedades. Comunicación en salud. Periodismo. Olas de noticias. 
